\title{
Elinikäinen oppiminen hallintavallan muotona
}

\author{
Ruotsalainen Andreas Fejes on julkaissut ahkerasti artikkeleita \\ ja kirjoja aikuiskoulutuksesta ja elinikäisestä oppimisesta \\ näkökulmanaan foucault'lainen käsitys vallasta ja hallinnasta. \\ Hän työskentelee Linköpingin yliopiston aikuiskasvatustieteen \\ professorina.
}

A ndreas Fejesin tutkimuksen lähestymistavoista, kysymyksenasetteluista ja luonteesta saa käsityksen hänen yhdessä Katherine Nicollin kanssa toimittamastaan kirjasta Foucault and Lifelong Learning: Governing the Subject. Fejesin uusin, Magnus Dahlstedt kanssa yhteistyönä syntynyt kirja The Confessing Society: Foucault, Confession and Practices of Lifelong Learning jatkaa elinikäisen oppimisen ja hallinnallisuuden analysointia.

Vallan ja hallinnan analytiikka on koulutustutkimuksessa tätä nykyä aika vahva suuntaus. Sen taustana on erityisesti uusliberalistisen koulutuspolitiikan nousu, kokonaisten koulutusjärjestelmien uudelleenjärjestelyt markkinaideologian mukaisiksi sekä talouden entistä vahvempi vaikutus kaikkiin kulttuurisiin instituutioihin.

\section{AIKUISOPPIJAN MUOKKAAMINEN}

2000-luvun alussa Fejes aloitti tutkimalla muun muassa iltalukion historiaa Ruotsisssa. Väitöskirjatutkimustaan varten $(2005$; 2006a) hän analysoi aikuisopiskelijan (den vuxna studerande, adult learner) konstruoimista Ruotsissa 1900-luvulla. Kysymys on oppivan subjektin rakentamisesta, ja niistä keinoista, joilla tietynlaista subjektia tuotetaan.

Foucault'laisessa lähestymistavassa valta on keskeinen käsite, joskaan ei aivan totunnaisessa merkityksessä. Foucault'lle valta on relationaalista ja tuottavaa: valta toteutuu toimivien ihmisten kautta, ei niin, että yksilöt olisivat vallankäytön päätepiste kohteen merkityksessä. Tieto ja valta ovat yhtä. Kun ihmiset toimivat itseään ja olosuhteitaan koskevan tiedon varassa, valta toteutuu heidän järkeilyissään 
ja toimissaan. Hallintavalta on vahvimmillaan silloin, kun yksilöt päättävät omaan vapaaseen harkintaansa perustuen toimia niin, että he samalla tulevat toteuttaneeksi taloudellista hyötyä tuottavan toimijan ideaalia. Nykyisessä hallinnassa on ennen kaikkea kysymys väestöjen työvoimapotentiaalin maksimaalisesta käyttöön ottamisesta ja hyödyntämisestä.

Fejesin tutkimukset aikuisopiskelijasta ja aikuisten koulutettavuudesta ovat yksi esimerkki tiedon ja vallan yhteen kietoutuneesta suhteesta. Nykyään kaikki aikuiset ajatellaan koulutettavina yksilöinä. Tämä idea "aikuisoppijasta" tai "elinikäisestä oppijasta" perustuu psykologiseen, sosiologiseen, kasvatustieteelliseen sekä tilastolliseen tietoon, joiden varaan taas eräänlainen "hyvän yksilön", tässä tapauksessa elinikäisen oppijan, määrittely rakentuu.

Elinikäistä oppimista koskeva vallitseva diskurssi on totuus elinikisestä oppimisesta, ja ihmiset itse normalisoivat itseään tuon totuuden kautta. Totuus on tässä yhtä vallan kanssa. Kun toimimme totuudenmukaisesti, valta toteutuu meidän kauttamme. Totuudet tietenkin vaihtelevat ajassa, ja niiden mukana myös yksilön järkeilyt ja toiminta.

Nykypäivän aikuiskoulutuksen keskiössä ovat sellaiset käsitteet kuin yksilöllisyys, työllistettävyys / työllistyvyys, kilpailukyky ja elinikäinen oppiminen. Fejesin (2005; Andersson \& Fejes 2005) tutkimus ruotsalaisella dokumenttiaineistolla jäljittää aikuisoppijaa käsittelevän diskurssin muutosta 1900-luvun puolivälistä 2000-luvulle. Tällaisen tutkimuksen yksi tarkoitus on asettaa nykyään itsestään selvinä otettujen totuuksien ja käsitysten "luonnollisuus" kyseenalaiseksi. Se, mitä tänään pidetään luonnollisena, on yhden aikakauden totuus. Aikakauden totuus muotoutuu aina vallitsevien valtasuhteiden mukaan.

\section{ELINIKÄINEN OPPIMINEN VASTAUKSENA EPÄVARMUUTEEN}

Fejesin noin puolen vuosisadan ajalta tekemä analyysi ruotsalaisella aineistolla osoittaa, että instituutioiden kautta tapahtuva "suora" hallinta on muuntunut itseohjautuvien yksilöiden kautta tapahtuvaksi hal- linnaksi. Pidemmässä tarkastelussa muutos on osa repressiiviseen käskyvaltaan perustuvan hallinnan muuntumista yksilöiden itsehallinnaksi.

Nykypäivän aikuisen kuuluu ottaa vastuu omasta kehittymisestään ja ymmärtää kaikki elämänalueet tilaisuuksina oppia ja kehittyä. Oppiminen ei rajaudu enää institutionaalisiin konteksteihin vaan levittäytyy kaikkialle. Se ei myöskään rajaudu tiettyihin yksilöihin, vaan koskee kaikkia. 1950-luvun diskurssissa tärkeällä sijalla oli yksilön kyvykkyys ja lahjakkuus sekä niiden määrittely - aikuisopiskelun yhtenä ongelmana oli ratkaista, kellä on aikuisena kyvykkyyden ansiosta potentiaalia opiskella ja oppia.

Hallinnan muutos näkyy myös esimerkiksi ohjauksen ja ohjauskäytäntöjen muutoksena. 1950-luvulla ohjaaja oli soveltuvuudesta ja kyvykkyydestä saatuun tietoon nojaava auktoriteetti, joka oli ratkaisevassa asemassa yksilön opiskelun ja oppimisen suhteen. Nykyisin, kun elinikäinen oppiminen kuuluu kaikille, yksilöt arvioivat itse riskit ja tekevät itse opiskeluaan ja oppimistaan koskevat ratkaisut käytössään olevan tiedon perusteella. Aiempi auktoriteetin kuulemiseen perustuvan ohjauksen yksisuuntainen suhde on muuttunut kaksisuuntaiseksi ja sisältää sen sijaan ohjausta saavan yksilön itsensä aktiivista reflektiota omista kyvyistä ja vajavaisuuksista.

Nykyinen elinikäisen oppimisen diskurssi ei rajaudu vain koulutuksen alueelle, vaan siinä on kysymys kokonaisen elämänmuodon kuvaamisesta ja tulevaisuuden rakentamisesta. Diskurssi luo oman ja "yhteiskunnan" edun ymmärtävän, järkevän yksilön, jonka oikean toiminnan varaan parempi tulevaisuus rakentuu.

On kuitenkin olemassa riskiryhmiä, jotka ovat vaarassa jäädä elinikäisen oppimisen ulkopuolelle. Diskurssissa väistämättäkin "normaalin" vastapooliksi rakentuu "toinen", ne joiden elämässä jatkuva ja kaikkialla tapahtuva oppiminen ei toteudu. Elinikäisen oppimisen kautta tapahtuva hallinta on hallintaa paremman tulevaisuuden rakentamisen nimissä.

Fejes tähdentää, että on tärkeää huomata niin koko elinikäisen oppimisen diskurssin kuin esimer- 


\section{ELINIKÄINEN OPPIMINEN}

\author{
N $\ddot{A} H D \ddot{A A} N$ VASTAUKSENA \\ KIIHTYV ̈̈LLÄ NOPEUDELLA
}

TAPAHTUVIIN

YHTEISKUNNALLISIIN

MUUTOKSIIN.

kiksi normaalin ja epänormaalin määrittelyjen riippuvan vallitsevista yhteiskunnallisista valtasuhteista. Elinikäinen oppiminen kokoaa yhteen kaikki ne yksilöä muokkaavat toimenpiteet, joiden toteutumisen avulla kansallisvaltio voi pysyä mukana kansainvälisessä kilpailussa. (Fejes 2006b.) Vaikka Fejes onkin tehnyt tutkimuksensa Ruotsissa laaditun dokumenttiaineiston perusteella, ei ole vaikea nähdä, että elinikäisen oppimisen diskurssi on ylikansallista, kansallisin nyanssein ryyditettynä.

\section{TYÖN PUUTTEESTA TYÖLLISTETTÄVYYTEEN}

Puhetapojen ja totuuksien muutokset heijastuvat esimerkiksi puheeseen työttömyydestä ja työn puutteesta (esim. Fejes 2010). Siinä missä ennen puhuttiin työttömyyden aiheutuvan työn puutteesta, nykyisissä politiikkadokumenteissa puhutaan yksilöiden työllistettävyydestä.

Työttömyys on kääntynyt yksilön ongelmaksi, ja syynä ovat yksilön ominaisuudet. Työttömyys on seurausta työllistyvyyttä edistävien taitojen puutteesta. Työllistettävyys käy työttömyyden selityksestä ja heikko työllistettävyys työttömyyden legitimoijasta. Tässä puhetavassa vastuu työllisyydestä ja työttömyydestä on yksilöllä itsellään. Katse on kääntynyt eriarvoisuutta tuottavista rakenteista yksilön muokkaamiseen. Yksilön vastuulle jää myös ryhtyä toimenpiteisiin oman työllistettävyytensä parantamiseksi.

Sopuisan ja itseään normalisoivan kansalaisen kasvatus ja poikkeavuuksien oikominen alkavat jo kouluasteella (ks. Dahlstedt, Fejes \& Schönning 2011).
Poikkeavuuksiin ei tartuta enää kovakouraisesti, vaan houkuttelemalla poikkeavat dialogiin ja motivoimalla vaikeita oppilaita arvioimaan itseään ja toimintaansa ikään kuin ulkopäin. Oppimalla vertaamaan itseään tavoiteltuun minään tai normaaliin esimerkiksi aggressiivisesti käyttäytyvät saavat eväitä ryhtyä muokkaamaan itseään vastuullisen kansalaisen suuntaan.

\section{TIETO ON VALTAA}

Elinikäisestä oppimisesta on tullut totuus koko teollistuneessa maailmassa, mikä näkyy erityisen hyvin vahvojen kansainvälisten toimijoiden, kuten EU:n komission ja OECD:n, ajamassa politiikassa. Elinikäinen oppiminen nähdään vastauksena kiihtyvällä nopeudella tapahtuviin yhteiskunnallisiin muutoksiin, globalisaation aiheuttamiin taloudellisiin ja sosiaalisiin paineisiin sekä tulevaisuuden epävarmuuteen. Elinikäinen oppiminen ja oppivan yhteiskunnan luominen ovat ainoa mahdollisuus pysyä mukana kansallisvaltioiden ja maanosien välisessä kilpailussa. Oppiva yhteiskunta on mahdollinen vain, jos meistä kaikista tulee itseään kehittäviä ja kehityksestään huolehtivia subjekteja. (Nicoll \& Fejes 2008.)

Tutkimuksen onkin syytä analysoida nimenomaan sitä, miten tämä "elinikäinen oppiminen" tulee yleisesti hyväksytyksi. Kysymys on vallasta: miten elinikäisestä oppimisesta erilaisine vaatimuksineen, toimenpiteineen ja käytäntöineen tulee totuus, miten yksilöt omaksuvat tämän totuuden osaksi omaa elämäänsä ja miten väestöt muokkaavat toimintaansa sen mukaisesti.

Katherine Nicollin kanssa kirjoittamassaan artikkelissa Mobilizing Foucault in studies of lifelong learning Fejesin (Nicoll \& Fejes 2008) omaksuma lähestymistapa elinikäisen aikuiskoulutuksen ja oppimisen tutkimiseen tulee hyvin valaistuksi. Foucault'laisperäinen käsitys vallasta poikkeaa niin kutsutusta perinteisestä valtakäsityksestä, jossa valta paikannetaan vallankäyttäjän ja vallan kohteen välisessä asetelmassa vallankäyttäjään. Valta on ole- 
massa vain suhteissa ja toiminnassa. Se aktualisoituu teoissa ja toiminnassa ja näkyy siinä, miten toiminta muokkaa tai luo uutta toimintaa yksilöiden tai ryhmien välisissä suhteissa.

Kurivallan tilalle on tullut tietoon perustuva valta, joskaan kurivalta ei ole kokonaan kadonnut. Totuudet, itsestään selvyydet ja "terve järki" ovat hallintavallan tavallisimpia mekanismeja (Foucault 1980). Monissa Fejesin (esim. 2008a) analyyseissä on kysymys nykyisyyden historiallistamisesta (historisizing the present) sekä totuuksien ja käsitteiden merkitysten muuntumisesta ajassa.

\section{TUNNUSTUSYHTEISKUNTA}

Väitöstutkimuksesta lähtien Fejesin (2006) kiinnostuksen kohteena on ollut niin sanotun tunnustuksellisuuden yleistyminen osaksi subjektia. Meidän kaikkien pitäisi olla jatkuvasti valmiita puhumaan itsestämme, reflektoimaan tunteitamme ja toimiamme, pohtimaan suhdettamme "itseemme", kanssaihmisiin ja yhteisöihimme sekä tunnustamaan toiveemme, tavoitteemme ja vajavaisuutemme. Tunnustuksellisuuden tulo osaksi subjektia on samalla merkki vallan normalisoivasta voimasta. Valta on kaikkialla, ja se luo puitteet ajattelulle ja toiminnalle. Koulutuksessa tunnustamisen käytännöt ovat arkipäivää ja konkretisoituvat esimerkiksi opettamiskäytännöissä, opinto-ohjauksessa, neuvontapalveluissa, itsearvioinnissa, vertaistuessa. (Fejes 2008b; Fejes \& Dahlstedt 2013.)

"Tunnustusyhteiskuntaa" leimaa terapeuttinen eetos, jossa esimerkiksi julkisuuden henkilöiden tunteiden näyttämisestä ja "itsensä paljastamisesta" tulee entistä olennaisempi osa nykyihmisen luonnetta. Esimerkiksi Furedi (2004) sekä Ecclestone ja Hayes (2009) ovat niin ikään kiinnittäneet huomiota siihen, kuinka terapeuttinen eetos vaatii kansalaisia näyttämään "todelliset tunteensa", "sisimpänsä". Nykyihminen on hauras ja haavoittuvainen ja tarvitsee yhä enemmän pedagogista ja lääketieteellistä asiantuntemusta elämänsä arviointiin ja ratkaisujensa tueksi. Mutta yksilön on oltava avoin ja tunnustettava haavoittuvaisuutensa.
Media - erityisesti televisio ja sosiaalinen media on tärkein kanava, jonka kautta eetos on levittäytynyt myös niin sanottujen tavallisten ihmisen elämään. Terapeuttisen eetoksen yksi osoitus on politiikan henkilöityminen ja myös poliitikkojen "tunteellistuminen". Poliitikot hakevat äänestäjien hyväksyntää avaamalla medialla kotinsa ovet ja ruotimalla onnistumisistaan ja epäonnistumisistaan juontuvia tunteita julkisuudessa. Tunteva ja haavoittuvainen ihminen on politiikan julkisuudessakin nousemassa poliittisia tekoja tärkeämmäksi.

Tunteiden verbalisoiminen on tunnustusyhteiskunnan tärkein piirre. Terapeuttinen kulttuuri keskittyy yksilöön, ja yksilöä kannustetaan verbalisoimaan elämänsä ongelmat yksilön reaktioiksi ja tuntemuksiksi. Aiemmin sosiaalisina pidetyt ongelmat yksilöityvät ja purkautuvat nyt yksilön puheena omista epäonnistumisistaan. Kun epäonnistumiset, yksilölliset puutteet ja erilaiset vajavaisuudet (esimerkiksi suhteessa "markkinoiden vaatimuksiin") nähdään osana yksilön elämänkulkua tai suorastaan yksilön ominaisuuksina, helpotusta haetaan tunnustamisesta. Tunnustamisessa vaikeuksiin haetaan yksilökohtaisia ratkaisuja, jotka tuottavan kansalaisen kohdalla ovat usein pedagogisia: itsensä muokkaamista taloutta ja tuotannollisuutta palvelevien vaatimusten mukaisesti.

Confessing Society -kirjassa kuvataan, kuinka elinikäisen oppimisen käytännöt ovat omiaan hämärtämään koulutuksen, työn ja yksityselämän välisiä rajoja ja kuinka tunnustaminen leviää kaikille elämänalueille. Viimeisimpänä elinikäisen ohjauksen ajatus käytäntöineen tunkeutuu ennen yksityisenä pidettyyn sfääriin.

Kansalaiset ovat oppineet verbalisoimaan ja julkisesti esittämään elämänsä haasteena, jossa koulutuksen, työn ja yksityiselämän rajat ovat menettäneet merkityksensä. Tunnustamisesta on tullut olennainen osa subjektin muodostumisprosessia. Esimerkiksi Facebook on täynnä havainnollisia esimerkkejä siitä, kuinka ihmiset esittävät itseään korostaen "vahvuuksiaan" ja tunnustaen "heikkouksiaan". He 
asettavat kehittymishaasteita itselleen ja raportoivat muille elämästään yhtälailla työssä kuin vapaa-ajalla. Kaikesta on tullut julkista.

\section{LOPUKSI}

Fejes katsoo tutkimuksissaan elinikäistä oppimista ja oppimisyhteiskunnan luomista hallinnan analytiikan näkökulmasta. Se näyttää elinikäisen oppimisen osana historiallista muutosta.

Tarkastelun keskiössä on väestöjen hallinta muuttuvine käytäntöineen ja teknologioineen. Usein analysoitavana ovat yksilöön kohdistuvat toimenpiteet, jotka yhä useammin saavat dialogisen muodon. Valta on dialogin osapuolten välisissä suhteissa. Liberaalissa demokratiassa valta toteutuu yksilöiden vapauden kautta. Meillä on vapaus tehdä itseämme koskevia ja tulevaisuuteemme vaikuttavia päätöksiä, mutta meillä ei ole vapautta luoda totuutta maailmasta, jossa toimimme. Totuuden otamme itsestään selvyytenä; tai itsestään selvyydet otamme totuuksina.

Kansalaisten muokkaaminen instituutioiden ja talouden palvelukseen ei tietenkään ole uusi ilmiö, mutta uusliberalistinen politiikan läpilyönti on merkinnyt muutosta myös väestöjen moraaliseen sääntelyyn. Yksilön vastuu ja kilpailullisuus kietoutuvat yhä tiiviimmin yhteen, ja niiden varaan rakentuu myös uusi totuus yksilöstä ja hänen ympäristöstään sekä mahdollisuuksista elää kunniallisesti.

Heikki Silvennoinen

Kasvatustieteiden professori

Turun yliopisto

\section{LÄHTEET}

Andersson, P. \& Fejes, A. (2005) Recognition of prior learning as a technique for fabricating the adult learner: a genealogical analysis of Swedish adult education policy. Journal of Education Policy 20 (5), 595-613.

Dahlstedt, M., Fejes, A. \& Schönning, E. (2011) The will to (de)liberate: shaping governable citizens through cognitive behavioural programmes in school. Journal of Education Policy 26 (3), 399-414.

Ecclestone, K. \& Hayes, D. (2009) The Dangerous Rise of Therapeutic Education. London: Routledge.

Fejes, A. (2003) Kvällsgymnasier - ett vägval i vuxenutbildningens historia. Vägval i skolans historia: Tidskrift från föreningen för svensk undervisningshistoria (4), 11-13.

Fejes, A. (2005) New wine in old skins: Changing patterns in the governing of the adult learner in Sweden. International Journal of Lifelong Education, 24(1), 71-86.

Fejes, A. (2006a). Constructing the adult learner: a governmentality analysis. Linköping Studies in Education and Psychology 106. Linköping University.

Fejes, A. (2006b) The planetspeak discourse of lifelong learning in Sweden: what is an educable adult? Journal of Education Policy 21 (6), 697-716.
Fejes, A. (2008a) Historicizing the lifelong learner: governmentality and neoliberal rule. Teoksessa A. Fejes \& K. Nicoll, K. (toim.) 2008. Foucault and Lifelong Learning: Governing the Subject. Abingdon: Routledge, 87-99.

Fejes, A. (2008b) To be one's own confessor: Educational guidance and governmentality. British Journal of Sociology of Education 29(6), 653-664.

Fejes, A. (2010) Discourses on employability: constituting the responsible citizen. Studies in Continuing Education 32 (2), 89-102.

Fejes, A. \& Dahlstedt, M. (2013) Confessing Society. Foucault, confession and practices of lifelong learning. London: Routledge.

Fejes, A. \& Nicoll, K. (toim.) 2008. Foucault and Lifelong Learning: Governing the Subject. Abingdon: Routledge.

Foucault, M. (1980) Power/Knowledge: selected interviews and other writings 1972-1977. New York: Pantheon.

Furedi, F. 2004. Therapy culture. London: Routledge.

Nicoll, K. \& Fejes, A. (2008) Mobilizing Foucault in studies of lifelong learning. Teoksessa A. Fejes \& K. Nicoll, K. (toim.) 2008. Foucault and Lifelong Learning: Governing the Subject. Abingdon: Routledge, 1-18. 